\title{
Unbecoming Jurors and Unreasoned Verdicts: Realising Integrity in the Jury Room
}

\author{
JOHN JACKSON $^{*}$
}

\section{Introduction}

In an article written over ten years ago I observed that the jury system in the common law world has survived throughout the years by being able to adapt to different legal and political cultures. ${ }^{1}$ It might have been more accurate to say that this is one of the reasons why it has survived in criminal cases. In many but not all parts of the common law world ${ }^{2}$ the demise of the civil jury has been remarkable. In his Hamlyn lectures 30 years ago Lord Hailsham illustrated this quite graphically when he said that at the time of the Great Warover a century ago now-almost every issue of fact that had to be determined before the superior courts in England and Wales outside the Chancery Division was tried by a jury. ${ }^{3}$ Yet by 1983 the civil jury was arguably a thing of the past. One of the reasons for this decline would seem to be that jurors were increasingly considered less suited than professional judges to the role that was expected of them in modern civil litigation.

There is much greater support for the role of the jury continuing in criminal cases, at least in England and Wales, where it has been argued that the jury fulfils broader functions. It plays an important educative role in informing citizens about the workings of the criminal process and about the content of the criminal law, and makes the criminal law more transparent and accessible. ${ }^{4}$ In these ways it can be claimed that the jury plays

\footnotetext{
* Thanks are due to participants at the UNSW conference and at a seminar at the City University, London in May 2013 for their comments on earlier drafts of this chapter. Special thanks are due to Mark Coen, Jonathan Doak, Nancy Marder, Paul Roberts and Simon Young for their detailed comments on earlier drafts and to Thom Brooks, Niamh Howlin, Jill Hunter and Luke Marsh for providing me with ideas and assistance.

1 JD Jackson, 'Making Juries Accountable' (2001) 50 American Journal of Comparative Law 477.

2 The US civil jury is still a potent force: see R Litan (ed), Verdict: Assessing the Civil Jury System (Washington, Brookings Institution, 1993).

${ }^{3}$ Lord Hailsham, Hamlyn Revisited: The British Legal System Today (London, Stevens, 1983).

4 See M Redmayne, 'Theorising Jury Reform' in A Duff, L Farmer, S Marshall and V Tadros (eds), The Trial on Trial (2): Judgment and Calling to Account (Oxford, Hart Publishing, 2006) 99 (suggesting that arguments for the jury can be classified as belonging to three broad perspectives: court-centred (good fact-finders), citizen-centred (good governance) and defendant-centred (offering protection to defendants)). See also T Brooks, 'The Right to Trial by Jury' (2004) 21 Journal of Applied Philosophy 197, 204.
} 
an important instrumental role in promoting the integrity of the criminal law and the criminal justice system as a whole. There has been less satisfaction, however, about the way jurors have conducted themselves in certain cases-regarding what might be described as the personal integrity of jurors. ${ }^{5}$ In recent years, periodic crises of confidence have sparked debate and suggestions for reform to prevent jurors acting prejudicially or otherwise flouting their obligations, the latest example being the Law Commission's proposals to deal with jurors who try to search for details of the case they are trying on the internet. ${ }^{6}$ These crises of juror misconduct have gone hand in hand with a more general expectation that jurors should be made more accountable for their behaviour, which would seem to be linked to growing demands for all manner of public bodies to be made more accountable. ${ }^{7}$ So long as juries were traditionally of the community they did not need to be accountable to the community any more than to a hierarchical bureaucratic authority. ${ }^{8}$ But the increasingly diverse nature of communities from which juries are chosen has engendered less confidence in their ability to apply undifferentiated community standards in their decision-making.

Against this backdrop, it is imperative to consider how best to ensure that jurors do not fall short of their obligations. Section 1 of this essay argues that an undue focus on individual juror impropriety has diverted attention away from how we want the jury as a collective decision-making body to act, and that there should be clearer standards in this regard. There is a need to shift the debate away from the personal integrity of jurors towards the 'institutional' integrity of the jury as a decision-making body in the criminal process. The focus here is on a third kind of integrity - the integrity of the criminal process - which can be differentiated both from the integrity of the criminal justice system as a whole (including substantive criminal law) and from the personal integrity of individual jurors. ${ }^{9}$ Comparative and empirical scholarship has illuminated the important role that the jury plays in promoting the adversarial features of an oral and public trial. ${ }^{10}$ But the openness

\footnotetext{
5 But cf J Hunter, Jurors' Notions of Justice (Sydney, University of New South Wales, 2013) 35, for empirical evidence that jurors do attach importance to personal integrity in terms of abiding by the instructions given to them by the judge.

${ }^{6}$ See Law Commission, Contempt of Court (1): Juror Misconduct and Internet Publications (London, Stationery Office, 2013).

7 Jackson, above n 1.

8 MR Damaška, 'Structures of Authority and Comparative Criminal Procedure' (1975) 84 Yale Law Journal 480 .

9 Some commentators have distinguished between the integrity or 'legitimacy' of the criminal justice process as a whole, and narrower aspects of integrity such as the principle of judicial integrity, the integrity of the trial and the integrity of the verdict. See A Ashworth, 'Exploring the Integrity Principle in Evidence and Procedure' in P Mirfield and RJ Smith (eds), Essays for Colin Tapper (London, Butterworths, 2003); L Hoyano, 'What is Balanced in the Scales of Justice? In Search of the Essence of the Right to a Fair Trial' [2014] Criminal Law Review 3. Cf IH Dennis, 'Reconstructing the Law of Criminal Evidence' (1989) 42 Current Legal Problems 21; TRS Allan, 'The Concept of a Fair Trial' in E Attwooll and D Goldberg (eds), Criminal Justice (Stuttgart, Franz Steiner Verlag, 1995).

10 The link between the principles of the public oral criminal trial and the jury was made long ago by the nineteenth-century German criminal law scholar, CJA Mittermaier, who used this thesis to argue against the introduction of the 'Schöffengericht' mixed court in Germany: see A Koch, 'CJA Mittermaier and the 19th Century Debate About Juries and Mixed Courts' (2000) 72 Revue International de Droit Pénal 347. For more recent explorations, see E Knittel and D Seiler, 'The Merits of Trial by Jury' (1972) 30 Cambridge Law Journal 316, 318; J Jackson and S Doran, Judge without Jury: Diplock Trials in the Adversary System (Oxford, Clarendon Press, 1995); J Jackson, 'The Value of Jury Trial' in Attwooll and Goldberg, above n 9, 79.
} 
that juries help promote during the course of the trial stands in sharp contrast to the secrecy of their deliberations in the jury room. Section 2 contends that, as jurors become more active in their role as fact-finders, and more easily exposed to extraneous material, greater scrutiny may be required of these closed proceedings with more directive judicial guidance specifying how deliberations should be conducted. Section 3 then confronts the question whether the greater 'judicial' responsibilities that such guidance entails should extend to mandating reasoned decisions for jury verdicts. Section 4 explores possible answers with the benefit of lessons drawn from comparative experience, and the essay concludes with a brief recapitulation of the main arguments and their implications for the integrity of trial by jury.

\section{Falling Short: Periodic Crises of Confidence in the UK's Jury Systems}

Periodic crises of confidence over the course of the past 30 years have prompted the question whether juries, as presently constituted, can be trusted to conform with their oath to 'faithfully try the defendant and give a true verdict according to the evidence. ${ }^{11}$ It would be an exaggeration to claim that these crises have threatened the very survival of the criminal jury; there remains enduring support for the system, not least by prominent members of the legal profession and judiciary. ${ }^{12}$ But three particular concerns have come to light during this period, each of which has evoked a considerable degree of soul-searching.

The first concern which manifested itself most prominently in the 1980s and 1990s, until the passage of the Criminal Justice Act 2003, was that many juries were insufficiently representative of the population as a whole, and that this could skew decisions in favour of 'criminals'. Secondly, doubts have arisen from time to time, especially since the passage of the Human Rights Act 1998, as to whether the system sufficiently guarantees an independent and impartial tribunal, which is an essential component of a fair trial under Article 6 of the European Convention on Human Rights (ECHR). A third concern which has manifested itself more recently has been whether jurors' increasing access to extraneous information about the case they are deciding exacerbates the risk that verdicts are based unduly on such information rather than on the evidence in the case. These three concerns may be summarised as relating to: (a) representativeness; (b) impartiality; and (c) reliance on extraneous material.

11 Criminal Practice Directions 2015 [2015] EWCA Crim 1567, CPD VI 26E.1.

12 See eg the remarks of Lord Judge CJ, 'Jury Trials', Judicial Studies Board Lecture, November 2010, reported at http://www.lawgazette.co.uk/analysis/lord-chief-justice-fears-new-threats-to-jury-trial/58173.fullarticle (accessed 23 February 2016). Although this support remains strong, there have been calls from time to time for experiments to be made with other modes of trial, such as the Schöffengericht system of a judge sitting with lay assessors or more simply with trials by judge alone. See eg G Williams, The Proof of Guilt, 3rd edn (London, Stevens, 1963) 299-300; L Blom-Cooper, 'Judge and Jury, or Judge Alone' (2004) 44 Medicine, Science and the Law 6. Lord Hailsham himself argued in favour of greater experimentation with mixed courts in his Hamlyn lectures; and in his Review of the Criminal Courts of England and Wales (London, Stationery Office, 2002) Lord Justice Auld favoured greater use of this mode of trial (see Ch 7, [21-35]). See J Jackson, 'Modes of Trial: Shifting the Balance towards the Professional Judge' [2002] Criminal Law Review 249. 


\section{(a) Representativeness}

Throughout the 1980s and 1990s there were persistent allegations that many of those summoned for jury service were able to opt out of serving and those who actually sat on juries were often unfit for such service. A newspaper survey in The Times in 1988, backed up by evidence assembled by the Criminal Bar Association, claimed that the discretion to excuse individuals from jury service was so wide that people with property, education and wide experience were under-represented and that the selection of jury panels, and of individual jurors from the panels, was haphazard and primitive. ${ }^{13}$ Home Office research in 1999 indicated that 38 per cent of those summonsed for jury service were excused. ${ }^{14}$ In addition, large sections of the population were ineligible because of their occupation. The result, it was claimed, was that juries had gone from being, in Lord Devlin's resonant phrase, 'middle-aged, middle-minded and middle-class' to becoming predominantly young, unemployed or manual workers. ${ }^{15}$ This concern about juries being unrepresentative in a very different manner from the past led occasionally to periodic media panic that jurors were often criminals themselves, or were 'eye-balled' or intimidated by the accused or his family members or associates seated in the public gallery into arriving at perverse verdicts. ${ }^{16}$ One particular example arose out of the acquittal of a defendant in a high-profile murder case in 1993 which prompted a spate of media reports about how juries were representative of an 'increasingly undereducated and lawless population' which was pre-disposed against conviction. ${ }^{17}$

Although steps were taken in 1988 to make the jury in England and Wales more representative of the community at large by abolishing peremptory challenges, concerns about representativeness resurfaced in Auld LJ's Review of the Criminal Courts of England and Wales in 2001. ${ }^{18}$ Lord Justice Auld was particularly concerned that excusals from jury service were 'depriving juries of the experience and skills of a wider range of professional and otherwise successful and busy people', creating the impression 'voiced by many ... that jury service is only for those not important enough or clever enough to get out of it. ${ }^{19}$ In the light of this finding, Auld recommended that everyone should be eligible for jury service, save for the mentally ill, and no one should be excused as of right but only upon good cause. These proposals were enacted in section 321 and Schedule 33 to the Criminal Justice Act 2003, and as a result there has been a considerable narrowing of the exemptions from jury service and a potential broadening of the pool of persons who actually make up juries. ${ }^{20}$

While these new rules enable juries to draw upon a wider body of experience, Auld considered that there remained certain types of cases that were unsuited for jury trial. Prominent among these were particular kinds of serious or complex fraud cases which

13 F Gibb, 'The Jury on Trial', The Times, 24-26 October 1988.

14 Home Office RDS, Jury Excusal and Deferral, Research Findings No 102 (London, HMSO, 1999).

15 Lord Devlin, Trial By Jury (London, Stevens, 1956) 20.

16 Gibb, above $\mathrm{n} 13$.

17 See $R v$ Wood (1996) 1 Cr App R 207, where the Court of Appeal commented that fairness demands that pressure should not be put on juries by the press or anyone else.

18 Auld Report, above $\mathrm{n} 12$

19 Ibid ch 5, [13].

20 R Taylor, M Wasik and R Leng, Blackstone's Guide to the Criminal Justice Act 2003 (Oxford, Oxford University Press, 2003) 66. 
have long been the subject of debate. ${ }^{21}$ Drawing upon a 'culmination of calls' over the years for these cases to be tried without a jury, ${ }^{22}$ Auld recommended that, as an alternative to trial by judge and jury, provision should be made for a judge to try such cases either with the assistance of selected lay members or, where the defendant consented, by the trial judge alone. Auld also considered that all young defendants charged with offences that merited a sentence of greater severity than the Youth Court could impose should no longer be tried by a judge and jury but instead by a Youth Court consisting of a judge of appropriate seniority sitting with at least two experienced magistrates. The only exception would be cases in which the defendant was charged jointly with an adult. Finally, drawing attention to the non-jury mode of trial by judge alone instituted for terrorist cases in Northern Ireland, Auld considered that defendants should be able to opt for trial by judge alone with the consent of the court in relation to a wide range of offences. This could provide 'a simpler, more efficient, fairer and more open form of procedure than is now available in many jury trials, with the added advantage of a fully reasoned judgment. ${ }^{23}$

The variety of cases identified in the Auld Report as being unsuitable for jury trial seemed to erode the principle that jury trial is the most suitable mode of trial for all serious cases. Parliament was stirred to embark on its own scrutiny of cases unsuited to jury trial. In the event, however, all of Auld's recommendations for non-jury trial proved too controversial and none was enacted, with the exception of the serious fraud proposals which were then never brought into force. ${ }^{24}$ Auld LJ's own recommendations for widening the pool of jury experience seemed to pre-empt his argument that certain cases were too complex for juries to deal with. ${ }^{25}$ Concerns about jury tampering, however, could not be alleviated by widening the jury pool. Parliament was persuaded to enact section 44 of the Criminal Justice Act 2003, which made provision for a judge to order non-jury trial where there is evidence of a 'real and present' danger that jury tampering would take place during a particular trial. ${ }^{26}$

\section{(b) Impartiality}

The Auld reforms broadening the jury pool seemed to defuse criticism that juries were insufficiently experienced to try complex cases and to allay the pervasive concern that was prevalent pre-Auld that juries could too easily succumb to rendering perverse verdicts. Prejudice, of course, whether conscious or unconscious, can always afflict individual jurors, but when personal bias manifests itself amongst a widely diverse group, it may be cancelled out by the views of other jury members. ${ }^{27}$ This expectation emphasises the importance

21 See eg Lord Roskill, The Fraud Trials Committee Report (London, HMSO, 1986).

22 D Corker, 'Trying Fraud Cases Without Juries' [2002] Criminal Law Review 283, 285.

23 Auld Report, above n 12, ch 5, [117].

24 Taylor et al, above n 20, 55-56. Criminal Justice Act 2003, s 43 has since lapsed; and further attempts at resurrection failed: S Doran, 'Trial by Judge Alone' in C Montgomery and D Ormerod, Fraud: Criminal Law Procedure (Oxford, Oxford University Press, 2008) C5.

25 Jackson, above n 12.

26 Ibid 56-61. This provision has been invoked only rarely: M Kennedy, 'Legal History Made As Four Stand Trial Without Jury', The Guardian, 10 January 2010. And see Twomey and Cameron and Guthrie v UK, Application Nos 67318/09 and 22226/12, 28 May 2013.

27 See $R$ v Abdroikov [2007] UKHL 37, [2007] 1 WLR 2679, [37]-[38]. 
of jurors acting collectively in the enterprise of reaching a verdict, working positively as a body and not just individually, to prevent prejudice infecting the deliberations in the case, a responsibility to which we shall return.

While the Auld reforms may have gone some way to reduce the risk of actual bias on the part of juries, the courts have stressed the importance of assessing a tribunal's impartiality from an 'objective' as well as a 'subjective' point of view. ${ }^{28}$ The question is not just whether the tribunal has in fact been biased, but also whether an objective and fair-minded observer would have legitimate doubts as to the impartiality of the tribunal. Two particular concerns have arisen in recent years. The first is that it is still possible-given the UK's demographics-for a randomly selected jury to contain only white jurors in cases where race becomes an issue, with the result that prejudice may ensue. ${ }^{29}$ Auld recommended the introduction of a scheme for selecting juries consisting of up to three people from any particular ethnic group in cases where the court considered that race might be an important issue in the case. ${ }^{30}$ This proposal did not find favour with the legislature. It would seem that in any circumstances where 'generic' bias manifests itself, the only recourse is to hope that any prejudiced or discriminatory behaviour is brought to light. ${ }^{31}$ It will then be for the judge to provide sufficient guarantees to exclude any objectively justified or legitimate doubts as to the impartiality of the tribunal. ${ }^{32}$ Given the secrecy of juror deliberations, bias can only come to light if jurors take the responsibility to speak up and expose unacceptable attitudes. This suggests again that it is not enough for jurors to act impartially in their decision-making as individuals. We may legitimately require of the 'good' juror, acting with integrity, that he or she raise any concerns about other jurors being biased, in the first instance with their fellow jurors and then, if this fails to make any headway, to expose any instances of prejudice to the judge. ${ }^{33}$

The second concern relates to the practice of permitting those with experience of the administration of justice to sit on a jury. Justice professionals might not approach the case with the same openness of mind as others unconnected with the legal system. Until the 2003 Act there was a long-standing rule that members of the legal profession and others associated with the administration of justice should be ineligible for jury service. ${ }^{34}$ Auld did not see why the undoubted risk of bias should be any greater than in the case of many others who are not excluded from juries and are trusted to put their prejudice aside. ${ }^{35}$ Another risk, however, is that system insiders may exert a disproportionate influence on other jurors

\footnotetext{
28 Piersack v Belgium (1983) 5 EHRR 169, [30]. See also Porter v Magill [2002] 2 AC 357.

29 The issue of racial bias and racism within the criminal justice system has received much exposure since The Stephen Lawrence Inquiry: Report of an Inquiry by Sir William Macpherson of Cluny, Cm 4262-I (London, Home Office, 1999). However, empirical data do not support systematic racial bias in jury verdicts: see C Thomas, Are Juries Fair? MoJ Research Series 1/10 (London, Ministry of Justice, 2010) 25-26.

30 Auld Report, above n 12, ch 5, [52]-[62].

31 See N Vidmar, 'Pretrial Publicity in Canada: A Comparative Perspective on the Criminal Jury' (1996) 79 Judicature 49 (distinguishing 'generic prejudice' from case-specific 'interest prejudice'). See also N Vidmar (ed), World Jury Systems (Oxford, Oxford University Press, 2000).

32 Sander $v$ United Kingdom (2001) 31 EHRR 44.

${ }^{33} R v$ Thompson [2010] EWCA Crim 1623, [2011] 1 WLR 200, [6] (holding that juror misconduct must immediately be drawn to the attention of the trial judge, or to the other jurors).

34 See Morris Committee, Report of the Departmental Committee on Jury Service, Cmnd 2627 (London, HMSO, 1965).

35 Auld Report, above n 12, ch 5, [30].
} 
precisely because of their experience with the justice system. ${ }^{36}$ Generally speaking, a line has been drawn by both the English courts and the European Court of Human Rights (ECtHR), whereby the mere fact that jurors have held positions as police officers or even prosecutors does not by itself give rise to any justified fears of bias. However, where such jurors have a direct connection with the instant case-if, for example, they are an employee of the prosecuting authority, or they have had some connection with the witnesses or the defendant-stricter scrutiny is required. ${ }^{37}$ In Hanif and Khan $v U K,{ }^{38}$ a juror, who was a serving police officer, knew one of the officers who testified at trial that one of the accused was alone in a car where a quantity of heroin was found. The accused claimed that he had a passenger in the car. The Court of Appeal upheld the convictions on the basis that it was not possible on the evidence to conclude that there had been a passenger. According to the Court, no fair-minded observer would believe that the jury's conclusion might have been brought about as a result of partiality on the part of the police officer juror. The ECtHR, however, considered that although there was nothing to suggest that the police officer juror had actually been biased:

$[\mathrm{W}]$ here there is an important conflict regarding police evidence in the case and a police officer who is personally acquainted with the police officer witness giving the relevant evidence is a member of the jury, jury directions and judicial warnings are insufficient to guard against the risk that the juror may, albeit subconsciously, favour the evidence of the police. ${ }^{39}$

The Court dismissed the argument that the evidence as a whole may have favoured the police officer's account on the ground that it was not for the ECtHR to make its own assessment of the evidence presented at trial.

The ECtHR's refusal to consider the weight of the evidence as a whole in determining the question of bias emphasises the importance that is attached to the manner in which a decision is reached, as opposed to whether the decision itself is factually correct. In determining this question, the Court has focused less on whether the tribunal was subjectively biased than on whether there were objective doubts about its impartiality. Of course, the fact that, as the Court found, the individual police officer juror may have subconsciously favoured the evidence of the police does not necessarily in itself raise a doubt as to whether the jury as a whole was biased. There would appear to be a gap in the reasoning here, for in order to conclude that there was bias on the part of the jury deciding on the crucial conflict of evidence between the police evidence and the defence evidence, any bias on the part of the police officer juror must have disproportionately affected the jury as a whole (or raised an objectively justified suspicion that it had done so). While other jurors could be expected to resist any 'generic' bias on the part of the police officer juror, the fact that the juror knew the police witness (for over ten years and had worked with him on three occasions in the investigation of the same incident) meant that he had 'special' knowledge which could have unduly swayed an otherwise impartial jury.

\footnotetext{
36 P Hungerford-Welch, 'Police Officers as Jurors' [2012] Criminal Law Review 320.

${ }^{37} R v$ Abdroikov [2007] UKHL 37, [2007] 1 WLR 2679. See also $R v$ Khan [2008] EWCA Crim 531; Re Purcell's Application [2008] NICA 11; Armstrong v UK, Application No 65282/09, 9 December 2014.

38 (2012) 55 EHRR 16.

39 Ibid [148].
} 


\section{(c) Extraneous Material}

A related concern that arises from a juror's access to 'special knowledge' about a witness is that this knowledge may be shared with jurors and used against one of the parties in the case without the details being presented and scrutinised in open court. The exclusion of the parties from 'special knowledge' goes to the heart of a concern that has recently attracted considerable attention. Through the internet, in particular, jurors are now able to access extraneous material about the case much more easily than in the past. This additional information may then influence the outcome of the case, in defiance of jurors' oaths to give a true verdict according to the evidence in court. This kind of misconduct strikes at the heart of a fair trial. Such material may have improperly influenced the jury without a warning by the judge as to how it should be assessed. More fundamentally, as Lord Judge CJ observed:

If material is obtained or used by the jury privately, whether before or after retirement, two linked principles, bedrocks of the administration of criminal justice, and indeed the rule of law, are contravened. The first is open justice, that the defendant in particular, but the public too, is entitled to know of the evidential material considered by the decision-making body; so indeed should everyone with a responsibility for the outcome of the trial, including counsel and the judge, and in an appropriate case, the Court of Appeal Criminal Division. This leads on to the second principle, the entitlement of both the prosecution and defence to a fair opportunity to address the material considered by the jury when reaching its verdict. ${ }^{40}$

Convictions may be found unsafe where there is any prospect that the defendant has been adversely affected in any of these ways by the jury's exposure to extraneous material. ${ }^{41}$

That the problem of extraneous material is quite widespread has been illustrated by a number of appeals. ${ }^{42}$ The Criminal Cases Review Commission disclosed to the Law Commission that since 2006 it had been invited to investigate at least 27 cases concerning allegations about juror misconduct. Complaints ranged from jurors using mobile phones in court and having inappropriate access to information about the proceedings to having impermissible contact with someone connected to the case they were trying. ${ }^{43}$ Cheryl Thomas' research on juries in England and Wales found that 12 per cent of jurors surveyed in high-profile cases attracting media attention admitted looking for information on the internet, although in other, more routine cases this figure reduced to 5 per cent. ${ }^{44}$ Further follow-up research at Crown Court centres revealed that 23 per cent of jurors questioned were 'confused about the rule on internet use', 7 per cent of jurors admitted to looking up information about the legal teams in their trials and 1 per cent admitted to searching for information about parties in the case (other than the defendant)..$^{45}$ The previous Lord Chief Justice regarded the problem of internet misuse as posing a tangible threat to the very survival of the jury system. ${ }^{46}$

\footnotetext{
${ }^{40} R v$ Karakaya [2005] EWCA Crim 346, [2005] 2 Cr App R 5, [24].

41 Cf $R v$ Karakaya [2005] EWCA Crim 346, [2005] 2 Cr App R 5; $R v$ Marshall and Crump [2007] EWCA Crim 35.

42 A list of cases is cited in the Law Commission's Consultation Paper No 209, Contempt of Court (London, Stationery Office, 2012) [4.1].

${ }^{43}$ Ibid [4.27].

44 Thomas, above n 29.

45 C Thomas, 'Avoiding the Perfect Storm of Juror Contempt' [2013] Criminal Law Review 483, 490-91.

46 Auld Report, above n 12.
} 


\section{Integrity in the Jury Room}

When reflecting on documented examples of juror misbehaviour, it is important to emphasise the distinction between individual misconduct and its effect on the jury as a whole. One juror's misconduct will not jeopardise the decision-making of an entire jury unless it impacts on the other jurors; and this in turn depends on how other jurors respond. The collective nature of jury deliberations has been somewhat neglected in the anxieties generated by individual misconduct. Remedial action can, of course, be taken against individual jurors for various kinds of misconduct. The Law Commission's consultation paper cited numerous instances of juror behaviour which have been deemed to be misconduct and may amount to contempt of court. ${ }^{47}$ Judges have been instructed to warn jurors, as soon as they are sworn in, that behaviour such as discussing the case with anyone outside the jury, carrying out any inquiries or research into any aspect of the case themselves or taking account of media reports, may well amount to contempt which is an offence punishable with imprisonment. ${ }^{48}$ Following consultation, the Law Commission recommended that there should be a special criminal offence of intentionally seeking information related to the case that the juror is trying and Parliament has now created several offences which are designed to combat juror misconduct in this respect. ${ }^{49}$ While the creation of such offences may be the best means of conveying a consistent message to jurors in all cases of what exactly is being prohibited, and may have some deterrent value, ${ }^{50}$ the effectiveness of such an offence will be dependent on jurors disclosing their own misconduct or that of other jury members to the judge. This would seem to necessitate a direction that not only informs juries of the offence and of their need to act with personal integrity within the law, but also appeals to their collective responsibility to bring in a verdict in a manner that forecloses any reliance on extraneous information and respects the integrity of the trial process.

Following a series of criminal appeals involving juror irregularity, Lord Judge CJ in $R v$ Thompson ${ }^{51}$ emphasised the importance of the jury's collective responsibility. The verdict of the jury, he said, was the verdict of them all (or the requisite statutory majority), and their collective responsibility was not confined to the verdict:

It begins as soon as the members of the jury have been sworn. From that moment onwards, there is a collective responsibility for ensuring that the conduct of each member is consistent with the jury oath and that the directions of the trial judge about the discharge of their responsibilities are followed. Where it appears that a member of the jury may be misconducting himself or herself, this must immediately be drawn to the attention of the trial judge by another, or the other members of

\footnotetext{
47 Law Commission, above n 42, 62-63.

48 See Judicial Studies Board, Crown Court Bench Book: Directing the Jury (2010). For high-profile examples of jurors sentenced to imprisonment for contempt, see AG v Dallas [2012] EWHC 156 (Admin), [2012] 1 WLR 991; AG v Fraill [2011] EWCA Crim 1570, [2011] 2 Cr App R 21.

49 Criminal Justice and Courts Act 2015, ss 71(1), 72 and 73. The Irish Law Reform Commission has recommended a specific offence prohibiting jurors from making independent investigations and internet searches: LRC 207-2013, Jury Service (Dublin, Law Reform Commission, 2013).

${ }^{50}$ But this is doubted by JR Spencer, 'The Law Commission's Consultation Paper on Contempt of Court' [2013] Criminal Law Review 1, 2. The Law Commission, above n 6, [3.49], [3.61]-[3.65], noted that jurors may be loath to get their fellow jurors into trouble, and that comparative experience provides no clear evidence of the mooted deterrent effect of criminalisation. See also Hunter, above $\mathrm{n} 5$.

51 [2010] EWCA Crim 1623, [2011] 1 WLR 200.
} 
the jury. So, if for example, an individual juror were to be heard saying that he proposed to decide the case in a particular way regardless of his oath to try it on the evidence, or he were demonstrating a bias based on racism or some other improper prejudice, whether against a witness or the defendant, these things must be reported to the trial judge. So must outside interference, such as imparting information of views apparently gathered from family or friends, or using a mobile phone during deliberations, or conducting research on the internet. The collective responsibility of the jury for its own conduct must be regarded as an integral part of the trial itself. ${ }^{52}$

This is an important statement in emphasising that juror behaviour in the jury room is part of the trial. It does not, of course, form part of the open proceedings of the trial but it can be said to be part of its closed proceedings. Private deliberations cannot be regulated directly by the judge (except perhaps after the fact); they are perforce secret and so they must instead be regulated by the jurors themselves. But in giving directions on how jurors should behave, there is a risk that too much emphasis may be put on jurors' responsibility to respond to irregularity. Rather than emphasise what jurors should not do and the procedures for remedying misconduct, the integrity of the closed proceedings as a whole might be better served if clearer instructions were given as to how jurors should conduct themselves in the jury room.

At the end of the trial, judges sum up on the evidence and expend much time on directing jurors in terms of what Roberts and Zuckerman call 'forensic reasoning rules. ${ }^{53}$ But in her research, Thomas found that jurors would like more instruction on how they should go about the task of deliberation. ${ }^{54}$ In $R v$ Thompson the Court of Appeal acknowledged this research finding but considered that, like any other body of individuals called upon to examine evidence before reaching a conclusion, each deliberating jury would have its own dynamics and ways of working. Trial judges could therefore give only general guidance, in terms of reminding the jury that each member has an equal responsibility for the verdict, that it is inevitable that different views will be expressed about different features of the case, and that there must be reasonable give and take between the members of the jury, with an opportunity for each to be heard and his or her opinions considered. ${ }^{55}$ Yet this would appear to fall short of the type of guidance juries want. In a follow-up study, Thomas found a desire for more concrete guidance about numerous aspects of jury deliberation, including what to do when confused about a legal issue, how to ensure that jurors are not unduly pressurised into reaching a verdict, how to start deliberations and what to do if something goes wrong during deliberations. ${ }^{56}$ Judges have always been reluctant to give jurors any blueprint for their deliberations. But jurors could be given more direction on how to act

52 Ibid [6]. Generally, see Crown Court Bench Book, above n 48, 9.

53 P Roberts and A Zuckerman, Criminal Evidence, 2nd edn (Oxford, Oxford University Press, 2010) 662-63.

54 Thomas, above n 29, 39-40. See also J Goodman-Delahunty, N Brewer, J Clough, J Horan, J Ogloff and D Tait, Practices, Policies and Procedures that Influence Juror Satisfaction in Australia: Report to the Criminology Research Council July 2007 (Canberra, Australian Institute of Criminology, 2008) 139.

55 [2010] EWCA Crim 1623, [2011] 1 WLR 200. Cf the wording of the 'Watson direction', articulated in $R v$ Watson [1988] QB 690,700, which may be given by judges as part of the summing-up or as a last resort after a jury is still unable to reach a majority verdict: 'Each of you has taken an oath to return a true verdict according to the evidence. No one must be false to that oath but you have a duty not only as individuals but collectively. That is the strength of the jury system. Each of you takes into the jury box with you your individual experience and wisdom. You do that by giving your views, listening to the views of others. There must necessarily be discussion, argument and give and take within the scope of your oath. This is the way in which agreement is reached. If unhappily, one of you cannot reach agreement, you must say so.'

56 Thomas, above n 45, 496-97. 
with the integrity that is required of any judicial body adjudicating in a criminal trial. In particular, they could be told more about what responsibilities they have as a body, and not just individually, to adhere to their pledge to give a 'true verdict according to the evidence.' ${ }^{57}$

Guidance to jurors might begin by emphasising that, although they come from the community as citizens, their role in the proceedings is to act as a quasi-judicial body, with special responsibilities. The nature of the lay judicial role is, assuredly, somewhat different from that of the professional judge. ${ }^{58}$ There has been much debate about the propriety of jurors exercising a power of 'nullification. ${ }^{59}$ The oath that judges swear-to do right after the law ${ }^{60}$ - is absent from the jurors' oath which (as we have seen) is to 'faithfully try the defendant and give a true verdict according to the evidence'. I have argued elsewhere that although jurors do not need to bring in a verdict according to the law, they are bound to determine the case on the merits in accordance with the evidence. ${ }^{61}$ This responsibility allows them to maintain some 'role distance' ${ }^{62}$ from the classic judicial responsibility to uphold the law. However, this distance only extends towards jurors' refusal to apply the full rigour of the law to the defendant; it does not entitle them to convict upon some extra-legal standard.

Three sets of responsibilities would seem to come into play when directing juries on how to perform their 'judicial' role in accordance with their oath: (a) responsibilities that jurors owe to each other; (b) responsibilities in fact-finding; and (c) responsibilities to ensure fairness to the parties.

\section{(a) Responsibilities Jurors Owe to Each Other}

The first set of responsibilities comprises those which individual jurors owe to each other in the exercise of their collective function. Although jurors do not expressly swear to engage in group deliberations, by implication the oath 'to give a true verdict according to the evidence' bids them to do more than come to a personal view of the evidence. They must engage in the act of reaching a collective verdict, which is rendered possible only through joint deliberation. ${ }^{63}$ So long as they act within the role assigned to them, that is, to decide the

57 Cf US guidance on jury deliberations: American Judicature Society, Behind Closed Doors: A Guide for Jury Deliberations (Des Moines IA, American Judicature Society, 1999). I am grateful to Nancy Marder for this reference.

58 Jackson and Doran, above n 10, 223, 293-94.

59 See RF Schopp, 'Verdicts of Conscience: Nullification and Necessity as Jury Responses to Crimes of Conscience' (1996) 69 Southern California Law Review 2039; T Brooks, 'A Defence of Jury Nullification' (2004) 10 Res Publica 401; M Mattravers, "More than Just Illogical": Truth and Jury Nullification' in A Duff, L Farmer, S Marshall and V Tadros (eds), The Trial on Trial (1): Truth and Due Process (Oxford, Hart Publishing, 2006); Redmayne, above n 4; K Crosby, 'Controlling Devlin's Jury: What the Jury Thinks, and What the Jury Sees Online' [2012] Criminal Law Review 15.

60 Judges in England and Wales swear 'to do right to all manner of people after the laws and usages of this Realm, without fear or favour, affection or ill will': see www.judiciary.gov.uk/about-the-judiciary/introductionto-justice-system/oaths (accessed 26 January 2016). For further discussion, see J Gardner, Law as a Leap of Faith (Oxford, Oxford University Press, 2012) chs 7 and 10.

61 Jackson, above n 1, 523. See also AAS Zuckerman, 'Law, Fact or Justice?' (1986) 66 Boston University Law Review 487.

${ }^{62}$ E Goffman, 'Role Distance' in Encounters: Two Studies in the Sociology of Interaction (Indianapolis, BobbsMerrill, 1961).

63 See the terms of the Watson direction, above n 55, which states that there must necessarily be discussion, argument and give and take within the scope of the oath. 
case in accordance with the evidence, jurors must respect each others' views. This extends to respecting personal conscience and not being bullied into violating it. ${ }^{64}$ There should also be respect for the confidentiality of their discussions. Judges, of course, already emphasise the importance of confidentiality in their charge to the jury. ${ }^{65}$ This may seem to sit oddly with the new emphasis being placed on the need for judges to alert jurors to bring 'any concerns' about fellow jurors to the attention of the judge. However, delays in reporting irregularities may infect the entire jury and its process of deliberation in such a way that it may be necessary to abort the whole trial when disclosures are finally made. ${ }^{66}$ If jurors wait until after the trial to allege misconduct, it may be too late to investigate, absent an allegation that extraneous material was used to reach the verdict. ${ }^{67}$ But judges need to be careful about what they ask jurors to report. In Thompson, the Lord Chief Justice acknowledged that when judges after the trial receive letters complaining about aspects of the deliberation process, it is hard to avoid the conclusion that the complaint is no more than a protest at the verdict. This suggests that judges should encourage jurors to report only serious irregularities tantamount to a breach of the juror's oath.

\section{(b) Fact-finding Responsibilities}

A second set of responsibilities relates to jurors' specific duties as triers of fact. The requirement to give a true verdict according to the evidence is aimed at ensuring that jurors do their best to act in accordance with the tenets of what Twining characterises as the 'rationalist tradition': making judgements under uncertainty by reasoning inductively from admissible, relevant evidence, using the 'available stock of knowledge about the common course of events ... supplemented by specialized scientific or expert knowledge. ${ }^{68}$ If they do this, we might say that they are acting with the epistemic integrity that is demanded of them, although this does not mean, of course, that they will always make correct judgements. As already mentioned, jurors will be guided by the judge on how to approach the evidence. However, there has been considerable discussion about jurors' capacity to follow judicial directions. ${ }^{69}$ It has been argued that giving these directions to juries at the close of evidence does not assist their understanding. ${ }^{70}$ Constructivist learning theory, proposing that learners construct knowledge for themselves, is now widely accepted by behavioural scientists. ${ }^{71}$ One implication is that greater efforts should be made to encourage jurors

\footnotetext{
64 As Judge LCJ said in $R v$ Thompson [2010] EWCA Crim 1623, [2011] 1 WLR 200, [9], continuing confidence in the jury system presupposes that jurors do not violate their consciences and can resist pressures to conform. See TA Green, Verdict According to Conscience (Chicago, University of Chicago Press, 1985).

65 Crown Court Bench Book, above n 48, 9.

${ }^{66}$ See eg $R v$ Thakrar [2008] EWCA Crim 2359, [2009] Crim LR 357 (jurors' failure to report misconduct was itself misconduct).

${ }^{67}$ R v Mirza, Connor and Rollick [2004] AC 1118 (HL).

${ }^{68}$ W Twining, Rethinking Evidence: Exploratory Essays, 2nd edn (Cambridge, Cambridge University Press, 2006) 76, Table 1, Model II, [6].

69 See generally, J Horan, Juries in the 21st Century (Annandale NSW, Federation Press, 2012) ch 3; C Ellsworth and A Reifman, 'Juror Comprehension and Public Policy: Perceived Problems and Proposed Solutions' (2001) 6 Psychology, Public Policy and the Law 788; NS Marder, 'Bringing Jury Instructions into the Twenty-First Century' (2006) 81 Notre Dame Law Review 449.

${ }^{70}$ Horan, above n 69, 77-78.

71 B Schäfer and W Wiegand, 'It is Good to Talk—Speaking Rights and the Jury' in Duff et al, above n 4.
} 
to raise issues with the judge while the trial is still proceeding. Horan has observed that trial by judge alone has been modified to take into account the benefits of constructionist learning theory; judges are active participants in trials. ${ }^{72}$ By contrast, jurors are still discouraged from taking any active role in the trial proceedings. They are often required to absorb oral evidence without resort to written or visual aids, and are discouraged from asking questions. ${ }^{73}$ Research in other jurisdictions indicates that juries may be helped in evaluating the evidence when they are encouraged to be more active, for example, by asking questions through the judge. ${ }^{74}$

The argument for encouraging greater juror participation, however, is not just about improving the quality of deliberations and fact-finding; it is also calculated to make jurors aware of their responsibilities and instil confidence in their decision-making role. When they cannot make sense of the evidence or they have a particular concern about its meaning or salience, jurors need to raise this first with each other, and then if necessary with the judge. For how can jurors act with integrity to their oath if they passively allow evidence to go over their heads or fail to engage with the evidence as best as they can?

It is one thing to encourage questions about evidence that has been admitted; quite another to encourage questions about perceived gaps in the evidence. Judges often tell jurors not to speculate about missing evidence. Yet it would appear that jurors are often alive to gaps in the evidence in a case. ${ }^{75}$ It might be preferable to encourage jurors to raise these concerns with the judge and the parties than to leave them to draw inferences against parties from missing evidence-or worse, as discussed below, to go off and make their own inquiries. The problem of gaps in the evidence may be less pronounced than in the past. There has been a trend across the common law world in favour of admitting more relevant evidence, particularly in the form of hearsay and bad character evidence. ${ }^{76}$ Some years ago, the point was made that with better educated and more literate jurors, the value of the old restrictive rules of evidence was being re-evaluated and many were being discarded or modified. ${ }^{77}$ But the admission of more information can create its own difficulties for jurors. In relation to the changes that have been made to the admissibility of bad character evidence in the Criminal Justice Act 2003, Roberts and Zuckerman have noted the shift in focus from evidentiary exclusion to judicial directions as the principal institutional mechanism for

72 Horan, above n 69, 77-78.

73 See M Coen and L Heffernan, 'Juror Comprehension of Expert Testimony: A Reform Agenda' [2010] Criminal Law Review 195, 205208.

74 See L Heuer and S Penrod, 'Juror Notetaking and Question Asking During Trials' (1994) 18 Law and Human Behavior 121; S Diamond, M Rose and B Murphy, 'Jurors' Unanswered Questions' (2004) 41 Court Review 20, available at http://www.law.northwestern.edu/faculty/fulltime/diamond/papers/unansweredQuestions.pdf (accessed 23 February 2016); BM Dann, V Hans and D Kaye, Testing the Effects of Selected Jury Trial Innovations on Juror Comprehension of Contested mtDNA Evidence: Final Technical Report (2004), available at www.ncjrs.gov/ pdffiles1/nij/grants/211000.pdf (accessed 23 February 2016).

75 W Young, N Cameron and Y Tinsley, Juries in Criminal Trials Part Two-A Summary of the Research Findings, Preliminary Paper 37, vol 2 (Wellington, NZ Law Commission, 1999) [4.8]-[4.11]. Jurors may, in particular, speculate about the accused's concealed criminal past: see L Laudan and RJ Allen, 'The Devastating Impact of Prior Crimes Evidence and Other Myths of the Criminal Justice Process' (2011) 101 Journal of Criminal Law and Criminology 493; M Coen, 'Hearsay, Bad Character and Trust in the Jury: Irish and English Contrasts' (2013) 17 International Journal of Evidence and Proof 250.

76 Whilst this is so in England and Wales, following the enactment of the Criminal Justice Act 2003, not all jurisdictions have followed this liberalising trend: see Coen, ibid.

${ }_{77} R v H[1995] 2$ AC 596, 613 per Lord Griffiths, cited in Roberts and Zuckerman, above n 53, 592. 
neutralising potential prejudice. ${ }^{78}$ The admissibility of bad character evidence can raise difficulties even when juries try to follow cautionary directions. Where, for example, bad character evidence is admitted to establish the accused's propensity to engage in conduct indicative of the crime charged, this inevitably invites some speculation about other aspects of the accused's past and may implicitly encourage independent background research on the accused. This brings us to a third set of responsibilities shouldered by juries, concerning the fairness of trial proceedings.

\section{(c) Fairness to the Parties}

Judicial summings-up naturally try to forestall unfairness towards witnesses and defendants during jury deliberations. But the question is whether enough is really done to explain to juries why it is particularly unfair for them to engage in independent research, given jurors' increasing access to extraneous information. In England and Wales, the present guidance in the Crown Court Bench Book requires judges to explain that in an open system of justice, in which the parties themselves decide what evidence to adduce at trial, it is upon that evidence alone that the jury must reach a verdict. ${ }^{79}$ Jurors are warned against seeking further information because the prosecution and defence would be unaware of it and unable to respond to it. But it must be questioned whether this is a sufficient explanation, given the fact-finding responsibilities already adverted to which require juries to take an open and inquiring attitude towards the evidence.

The difficulty here is that juries are being asked to do something that seems counterintuitive to ordinary experience. ${ }^{80}$ In a high-profile English trial of a celebrity defendant for perverting the course of justice, much publicity was given to '10 questions' that the jury asked of the judge. ${ }^{81}$ One question was whether a juror can come to a conclusion based on a reason that was not presented in court and has no facts or evidence to support it, either from the prosecution or defence. The jury was criticised by the trial judge for misunderstanding its essential function. It is impossible to know for certain exactly what the jury meant by such a question, and it would be a mistake to generalise about jury behaviour from a single case. ${ }^{82}$ Empirical data suggest, however, that jurors do not seem to appreciate the importance or do not understand the logic of restricting themselves to the information presented by the parties and the judge. In an illuminating empirical study in New South Wales, Hunter et al found that a prevalent misconception amongst certain jurors was that a juror's task is to determine the true facts in a case rather than whether the prosecution has proven a defendant's guilt beyond reasonable doubt. ${ }^{83}$ In their words, they prioritised 'objective truth' over 'procedural truth', or 'truth' over 'proof'. ${ }^{84}$

78 Roberts and Zuckerman, ibid 660.

79 Crown Court Bench Book, above n 48, 9.

80 According to Hunter, above n 5, 39, 'everyone's every day experiences endorse thorough research for important decision-making — for choosing a child's school, buying a car or choosing a job, a career, a new appliance or where to live. Most activities reward diligence in gaining an improved understanding of the world in which decisions are made. Not so jury duty.' See also Horan, above n 69, 168.

${ }^{81}$ C Davies, 'Vicky Pryce Trial: 10 Questions Jury Asked Judge', The Guardian, 20 February 2013.

82 C Thomas, 'Exposing the Myth' (April 2013) Counsel Magazine 25.

${ }^{83}$ J Hunter, D Boniface and D Thomson, What Jurors Search For \& What They Don't Get: Pilot Study-Juror Comprehension \& Obedience to Judicial Directions Against Juror Investigation (Sydney, UNSW, 2010). See also Hunter, above n 5.

${ }^{84}$ Hunter et al, above n 83, 16; Hunter, above n 5, 18. 
Existing judicial directions to counteract the problem of juror investigation and research were categorised by Hunter et al as related either to the integrity of the trial process or to matters of personal significance for the investigating juror. In their sample cases, they found that no trial judge provided a jury with a completely comprehensive explanation of the personal and procedural consequences that might follow should a juror disregard a direction not to engage in investigation or research. Hunter et al suggest that more should be done to link the features of 'adversarial justice' together to illustrate why it is both 'completely unnecessary and deeply inappropriate' for jurors to engage in extra-curial investigation or research. The Judicial Commission of New South Wales' suggested directions in the Criminal Trial Courts Bench Book provide illustrations explaining the nature of the criminal trial and the jury's function within it. They now spell out why making inquiries offends against the juror's oath to give a true verdict founded squarely on the evidence presented in open court.

Although these guidelines would appear to be improvements on existing directions, it may be asked whether they do enough to integrate the fact-finding responsibilities of the jury with standards of procedural fairness. The guidelines make reference to the frustration that jurors may feel about a lack of evidence but then go on to say, in effect, that jurors must put up with this, since making inquiries about anything to do with the case is 'not your function', which is instead, 'to decide on the evidence that has been placed before you whether the case for the Crown has been proved beyond reasonable doubt. ${ }^{85}$ Jurors may well understand from this why they must not go away and conduct independent research and make inquiries unconnected with the evidence in the case. But their job is to test the evidence that is placed before them to determine whether, taken in the round, it reaches the standard of proof beyond reasonable doubt. They do this in the light of examination by trial counsel, but at the end of the day jurors have to satisfy themselves, one way or another-and this is where the motivation to seek out further information gains a foothold.

Rosemary Pattenden has suggested that the distinction between extraneous and non-extraneous material is built on sand, because jurors must necessarily bring to the deliberations their own experience of life and general knowledge. ${ }^{86}$ She is critical of one case where the Court of Appeal in England and Wales quashed a conviction for possession of an offensive weapon after a judge failed to warn the jury not to act on any experiment carried out after receiving a report that a jury member had attempted to bring a pair of clippers into the court building to demonstrate some point in connection with the case. ${ }^{87}$ Pattenden contrasts this with the example of a juror who shares information which he knows about knives with the rest of the jury. The former juror is errant but the latter juror does the 'right thing'. She goes on to suggest that the distinction between general knowledge and illicit non-evidential material becomes even more tenuous when the internet is brought into the equation. A juror who is a lawyer would be allowed to pass on his knowledge about the meaning of a legal term but a lay member who looks the term up on the internet to refresh his memory from something the judge has said has

\footnotetext{
85 New South Wales Judicial Commission, Criminal Trial Courts Bench Book, [1-480] available at www.judcom. nsw.gov.au/publications/benchbks/criminal (accessed 26 January 2016).

${ }^{86}$ R Pattenden, 'Investigating Irregularities-United Kingdom (England and Wales)' (2010) 14 International Journal of Evidence and Proof 362.

${ }^{87} R v$ Thompson [2010] EWCA Crim 1623, [2011] 1 WLR 200, [84].
} 
misbehaved. ${ }^{88}$ The Court of Appeal has suggested that experts sitting on a jury may not introduce entirely new evidence into the case, let alone doing so at a time when neither party had been put on notice of it and given the opportunity to test it, and where the appellant in particular had not been given any opportunity to provide an explanation of it'. ${ }^{89}$ But there is a fine line between using one's specialised knowledge in analysing the evidence given in a case and actually giving new evidence oneself. ${ }^{90}$

A more realistic approach may be to concede that, while jurors are theoretically prohibited from checking up details on the internet, it is impossible in this day and age to prevent them from doing so, short of a form of sequestration that would bar access to the internet altogether. Better in these circumstances to concentrate on bringing home to jurors the important 'judicial' responsibilities they have. By swearing that they will try the case according to the evidence, jurors are by implication undertaking not to consider evidence which has not been admitted into court and has not been disclosed to the parties. The rationale for this restriction, it might be stressed, is not simply to satisfy some formal notion of 'procedural' fairness, but to ensure that evidence is properly tested before being acted upon. Upholding the integrity of the trial process is not to prioritise due process independent of truth-finding, but rather mandates finding the truth through a process of 'adversarial' argument. Failure to subject evidence to this process can result in flawed outcomes. ${ }^{91}$

It would seem to follow that if, by whatever means, jurors are aware of any information which has not been presented to the parties, their 'judicial' role requires that before sharing it with their fellow jury members, they must first disclose it to the judge so that the judge can decide how to proceed in consultation with the parties. Having considered counsel's submissions, the judge may decide to discharge the juror, along with the entire jury if there is a risk of contamination. Alternatively, the judge may decide that the disclosure would not risk an unfair trial.

\section{From Reasonable Verdicts to Reasoned Verdicts}

We have established that jurors assume important 'judicial' responsibilities to ensure that their deliberations are based on the evidence that has been adduced before them. But the juror's oath pledges jurors not only to try the defendant according to the evidence but also to 'give a true verdict according to the evidence'. Should jurors' responsibilities thus extend to giving a reasoned decision for their verdict?

\footnotetext{
88 Professional guidance to barristers and solicitors states that, if selected for jury service, they serve as private citizens and should not proffer legal advice or opinions: Bar Council, Guidance for the Bar Called for Jury Service (June 2004); Law Society, Solicitors Called for Jury Service-Guidance, 29 September 2005.

${ }^{89} R v$ Fricker, The Times, 13 July 1999.

90 See N Haralambous, 'Juries and Extraneous Material: A Question of Integrity' (2007) 71 Journal of Criminal Law 520. The distinction between expert opinion and factual testimony is not always easy to apply: see eg $R v$ Abadom [1983] 1 All ER 364.

${ }_{91}$ In Hunter et al's study, above $\mathrm{n} 83,36$, the dangers of flawed information, potential irrelevance and misleading jurors unskilled in its assessment rated as the most persuasive reasons for not engaging in private inquiries. On the relationship between 'adversarial' challenge and truth finding, see JD Jackson and SJ Summers, The Internationalisation of Criminal Evidence (Cambridge, Cambridge University Press, 2012) 362-63.
} 
Much has been written in recent years about whether the defendant's right to a fair trial requires a reasoned judgement. The Grand Chamber of the ECtHR in Taxquet v Belgium took the view that a fair trial entailed that the accused, and indeed the public, must be able to understand the verdict. This was 'a vital safeguard against arbitrariness. ${ }^{92}$ In proceedings conducted before professional judges the accused's understanding of his or her conviction stems primarily from the reasons given in the judicial decision. No such reasons are furnished by general jury verdicts. Yet the Grand Chamber drew back from the Chamber's ruling, which appeared to require that all decisions in criminal cases, including those given by lay juries, must be accompanied by reasons. The Grand Chamber in Taxquet accepted that, in the case of assize courts sitting with a lay jury, Article 6 does not require the lay jury to give reasons, although it does require an assessment of whether sufficient safeguards were in place to avoid any risk of arbitrariness and to enable the accused to understand the reasons for his conviction.

One of the safeguards specifically mentioned by the ECtHR is that directions or guidance are provided by the presiding judge to the jurors on the legal issues arising or the evidence adduced. Given this framework, it may often be relatively straightforward to infer why and more or less how a criminal jury has arrived at its verdict. ${ }^{93}$ The Lord Chief Justice has considered that 'a properly structured summing up followed by a verdict of the jury ... provides a complete understanding to the defendant and to the public of the reasons why the jury decided that the case against the defendant has been proved. ${ }^{94}$ In its admissibility decision in Judge $v U K^{95}$ where the applicant complained that a Scottish jury had convicted him of serious sexual offences without giving reasons, the ECtHR seemed to agree. According to the Court:

[I]n Scotland the jury's verdict is not returned in isolation but is given in a framework which includes addresses by the prosecution and the defence as well as the presiding judge's charge to the jury. Scots law also ensures there is a clear demarcation between the respective roles of the judge and jury: it is the duty of the judge to ensure the proceedings are conducted fairly and to explain the law as it applies in the case to the jury; it is the duty of the jury to accept those directions and to determine all questions of fact. In addition, although the jury are 'masters of the facts' ... it is the duty of the presiding judge to accede to a submission of no case to answer if he or she is satisfied that the evidence led by the prosecution is insufficient in law to justify the accused's conviction ... These are precisely the procedural safeguards which were contemplated by the Grand Chamber ... in Taxquet. In the present case, the applicant has not sought to argue that these safeguards were not properly followed at his trial. Nor has he suggested that the various counts in the indictment were insufficiently clear. Indeed, the essential feature of an indictment is that each count contained in it must specify the factual basis for the criminal conduct alleged by the prosecution: there is no indication that the indictment upon which the applicant was charged failed to do so. It must, therefore, have been clear to the applicant that, when he was convicted by the jury, it was because the jury had accepted the evidence of the complainers in respect of each of the counts in the indictment and, by implication, rejected his version of events. ${ }^{96}$

92 Taxquet $v$ Belgium [2012] 54 EHRR 26.

93 P Roberts, 'Does Article 6 of the European Convention on Human Rights Require Reasoned Verdicts?' (2011)

11 Human Rights Law Review 213.

94 Lord Judge CJ, above n 12.

95 Application No 35863/10, 8 February 2011.

96 Ibid [36]-[37]. 
It is important here to unravel the different strands of reasoning that a defendant and the public can draw from a verdict that has followed a contested trial. There is a difference between an accused understanding what evidence has been accepted in order to lead to his or her conviction, why that evidence has been accepted and how the decision was actually reached. The fact that the judge may have ruled that there is a case to answer implies rational evidential support for the conviction and the ECtHR also stressed the availability of procedural mechanisms in Scots law for quashing any conviction found on appeal to be a miscarriage of justice. But a reasonable verdict is not necessarily reasoned. Where, as on the facts in Judge, the evidential issue is whether to believe the complainer's evidence or whether to believe the defendant's evidence and a verdict of guilty follows, it is easy to understand that the reasons for the conviction were that the jury believed the complainer and not the defendant. But in a more complex case such as Taxquet where there were eight defendants allegedly involved in a conspiracy to murder and Taxquet was convicted of the pre-meditated murder of a government minister and the attempted pre-meditated murder of the minister's partner, a general verdict in itself (or, as was the case in Taxquet, simple 'yes' or 'no' answers to questions about the defendant's level of involvement and planning) may not be enough to explain his role in the conspiracy, especially since several co-conspirators were cleared of premeditation.

It is not enough to assert that the allegations against the defendant have been proved. There needs to be some evidence which the defendant can understand linking him or her to the elements of the charge. This is why closed material proceedings which have increasingly become a feature of the landscape in deportation and immigration cases in the UK are so problematic. ${ }^{97}$ The ECtHR has held that where detainees are facing lengthy periods of detention they must be provided with sufficient information about the allegations against them to enable them to give effective instructions to the special advocate who will represent their interests in the closed proceedings. ${ }^{98}$ But even if this minimal standard of disclosure is satisfied, when the closed proceedings end with a decision against the detainee which does not explain how the evidence links him to the allegations, he may not understand why the allegations have been upheld. ${ }^{99}$

In criminal cases the defendant has the benefit of knowing all the evidence against him, an opportunity to contest it and a careful summing up which should explain on what evidential basis a jury is at liberty to convict the defendant of the offences charged. As counsel for the UK government argued in Taxquet, in the course of a summing up a judge can give directions about the proper approach, or particular caution, to adopt in respect of certain evidence as well as providing the jury with information about the applicable legal rules. On that account the judge clarifies the constituent elements of the offence and sets out the chain of reasoning that should be followed in order to reach a verdict based on the jury's findings of fact. Where there is a verdict of guilty reached upon the basis of a summing up which articulates the route or, as may happen, the various routes argued by the prosecution

\footnotetext{
97 The Justice and Security Act 2013 extends this mechanism in civil proceedings. See J Jackson, 'Justice, Security and Right to a Fair Trial: Is the Use of Secret Evidence Ever Fair?' [2013] Public Law 720.

98 A v United Kingdom (2009) 49 EHRR 29; followed in Secretary of State for the Home Department v AF [2009] UKHL 28, [2010] 2 AC 269.

99 Cf Bank Mellat v HM Treasury (No 1) [2013] UKSC 38, [2014] AC 700, [69] (any party who has been excluded from a closed hearing should be told as much as possible about the court's reasoning and the evidence and arguments it received).
} 
towards liability, then the defendant will arguably be given a sufficient understanding of the reasons for the verdict.

But even if a defendant is indirectly given a sufficient understanding of the reasons for the verdict, should the jury itself not explain its own reasoning? Since the verdict is a 'performance' act that not merely declares the defendant's guilt but makes a normative judgement upon the accused from which grave consequences can follow, is the accused not owed a direct explanation from the jury as to what the reasons are for its verdict? ${ }^{100}$ Duff et al have argued that those calling an accused to account forfeit moral standing if they fail to communicate the normative grounds for their verdict. ${ }^{101}$ In certain recent decisions the UK Supreme Court has emphasised the importance of avoiding a sense of injustice on the part of those subject to legal decision-making. ${ }^{102}$ As Lord Reid put it, "justice is intuitively understood to require a procedure which pays due respect to persons whose rights are significantly affected by decisions taken in the exercise of administrative and judicial functions. ${ }^{103}$ Giving reasons is generally considered an important aspect of the judicial role, but juries have not traditionally been conceived as exercising a significant 'judicial' function in pronouncing their verdict.

Unlike appointed 'officials', juries pass a very personal judgement on their peers. ${ }^{104}$ Although unified into a panel, each juror retains an individual voice. There is no single 'official' condemnation that comes with the verdict, but rather a series of what may be very individual and different reasons each justifying the verdict as a matter of conscience. In such circumstances, so long as defendants have confidence in their peers as a group of randomly selected community members who can be expected to share similar values as themselves, they can accept an unreasoned verdict, without feeling any sense of injustice. Conversely, the more that values within the community diverge and a normative rift opens up between different sections of the community, the more likely a sense of injustice may be created by a verdict that is unexplained. A feeling of injustice might be particularly engendered on the part of those who are extradited from foreign countries and found guilty by an unaccountable jury completely unconnected to their community back in their home country. If they are extradited from countries which have no tradition of jury trial and where reasons are given as a matter of course by any tribunal adjudicating on the guilt of an accused, a sense of injustice might be further compounded by the lack of reasons given for their guilt. ${ }^{105}$

Rather than asking what is owed to defendants, we might instead consider what is required to do justice to the integrity of the criminal process. This raises a set of questions having less to do with the accused's sense of injustice than with the institutional integrity of what is owed by jurors as a judicial body intent on giving 'a true verdict according to the evidence'. We have seen that this task involves a commitment towards three distinct

\footnotetext{
100 On 'performative' utterances, see JL Austin, How To Do Things With Words (Oxford, Oxford University Press, 1962) $1-11$.

101 A Duff, L Farmer, S Marshall and V Tadros, The Trial on Trial (3): Towards a Normative Theory of the Criminal Trial (Oxford, Hart Publishing, 2007) 218-20. See also J Gardner, 'The Mark of Responsibility' (2003) 23 Oxford Journal of Legal Studies 157.

102 See eg Osborn v Parole Board; Booth v Parole Board; In re Reilly [2013] UKSC 61, [2014] AC 1115.

103 Ibid [68].

104 But cf R Lippke, 'The Case for Reasoned Criminal Trial Verdicts' (2009) 22 Canadian Journal of Law and Jurisprudence 313, 321 (arguing that jurors act as temporary state officials and should therefore fully and publicly justify their acts to satisfy the condition of political legitimacy).

${ }^{105}$ I owe this point to Paul Roberts.
} 
responsibilities: collective deliberation, rational fact-finding and fairness towards the parties within the context of the adversarial trial. The question then is whether a requirement to give reasons might contribute positively towards these ends and, if so, whether reasons for jury verdicts should become mandatory.

At one level, requiring reasoned verdicts would seem to aid the deliberation process as it would encourage jury members to engage in deliberation together rather than reach conclusions by means of arithmetical vote-counting. There has been some debate in the jury research literature as to whether jury deliberations are evidence-driven or verdict-driven. ${ }^{106}$ The former reasoning model starts with a review of the evidence without reference to the verdict and works towards agreeing upon the single most credible story of the events at the time of the alleged crime. The latter mode begins with a public ballot and embarks on deliberation by citing evidence in support of a specific verdict position. Both styles of deliberation may in fact be adopted by jurors, sometimes during the course of a single deliberation. ${ }^{107}$ The evidence-driven approach might seem closer to the deliberative ideal of being open to persuasion without feeling under pressure from other jurors. ${ }^{108}$ However, it is by no means clear whether a requirement to give reasons would encourage this mode of deliberation. Such a requirement might encourage jurors to develop a single story in the evidence-driven mode, but it might also, on the other hand, merely encourage early votetaking with subsequent deliberations amounting to little more than ex post facto rationalisation of a fait accompli.

Would requiring reasons enhance the quality of the jury's deliberations and improve the rationality of jury decision-making? The supposed rationality of jury deliberations has been widely debated. ${ }^{109}$ While many share an aspirational vision of juror rationality, ${ }^{110}$ others argue that heuristics and biases infect individual juror decision-making, and when jurors share a particular bias, group processes can magnify its effect. ${ }^{111}$ Whatever view is taken about the rationality of jury decision-making, however, it is hard to see how a requirement to give reasons would eradicate the biases that may infect decision-making. In recent years common law jurisdictions have encouraged trial judges to provide more structured summings-up to aid juror comprehension of the issues. Written directions to juriesvariously styled 'question trails', 'decision trees', structured question paths', 'flow charts' or 'routes to verdict' - are carefully tailored to the law and the evidence in the case, with the aim of assisting juries to adopt a logical, sequential approach to their deliberations. ${ }^{112}$

106 See R Hastie, S Penrod and N Pennington, Inside the Jury (Cambridge MA, Harvard University Press, 1983) 163-65; PC Ellsworth, 'Are Twelve Heads Better than One?' (1989) 52 Law and Contemporary Problems 247.

107 J Fordham, 'Illustrating or Blurring the Truth: Jurors, Juries, and Expert Evidence' in B Brooks-Gordon and M Freeman (eds), Law and Psychology: Current Legal Issues Volume 9 (Oxford, Oxford University Press, 2006) 338.

108 Hastie et al, above n 106, 165.

109 See eg C Callen (ed), Visions of Rationality in Evidence Law Symposium (2003) 4 Michigan State Law Review 847-1364.

110 See E Swift, 'Aspirational Optimism about Evidence Law' (2003) 4 Michigan State Law Review 1337, 1344 (characterising aspirational rationality as the consensus view of participants in Callen (ed), above n 109).

111 E Beecher-Monas, 'Heuristics, Biases, and the Importance of Gate-Keeping' (2003) 4 Michigan State Law Review 987; C Sunstein, Going to Extremes (New York, Oxford University Press, 2011). Contemporary research on biases and heuristics originates from A Tversky and D Kahneman, 'Judgment under Uncertainty: Heuristics and Biases' (1974) 185 Science 1124.

112 See eg J Ogloff, J Clough, J Goodman-Delahunty and W Young, The Jury Project 1-A Survey of Australian and New Zealand Judges (Canberra, Australian Institute of Judicial Administration, 2006). See also $R v$ Green [2005] EWCA Crim 2513; $R$ v Thompson (2010) EWCA Crim 1623, [2011] 1 WLR 200, [13]. The New South Wales Law Reform Commission has given support to integrated directions and written question trails, particularly in 
While such efforts may encourage juries to structure their reasoning process in a more orderly manner around the key questions to be determined, however, they do nothing in themselves to address any biases that might taint the deliberative process. Requiring reasons would make juries justify their answers to the questions asked. But the degree to which this would actually improve the quality of jury decision-making is debatable. Accountability of this kind may help to concentrate jurors' minds on how to justify the decision reached, but to the extent that reasons are merely ex post facto rationalisations of mental processes, they do not act as a constraint on the process of reaching the decision in the first place.

At this point, it may be argued that requiring reasons at least provides a basis for evaluating whether the jury is able to provide a rational justification for the verdict. In permitting the case to be heard by a jury, a judge is signifying that a verdict of guilty may be justifiable on the evidence, but when the jury enters the deliberation room we have no means of knowing how rational its members will be in coming to their decision. Accountability for the decision, on this argument, is not about improving decision-making, but rather about enabling an effective challenge to be made to a decision-making process that is necessarily opaque and lacking in transparency. At present, we are reliant on individual jurors to complain about any impropriety in the jury room to trigger further investigation by the judge. If reasons were required for the verdict there would at least be a basis for scrutinising in every case whether the jury has provided a rational justification for its verdict.

So long as the evidential basis for the jury's decision-making remains confined to information presented by the parties in open court, and litigants can influence judicial directions informing jurors how trial evidence should be considered and tested, it can be argued that the parties have sufficient 'input' control into the process to ensure that unreasoned verdicts are not tainted by adversarial deficit. As Damaška has explained, it is mainly through the parties' influence on what evidentiary material 'the procedural Sphinx hears and sees that the parties feel they can affect the outcome of the case.. ${ }^{13}$ Evidence law thus becomes a means not only of correcting factual error-it becomes the means of shoring up 'ex ante the legitimacy of inscrutable jury verdicts.' ${ }^{114}$ The more relaxed the evidentiary standards become, however, with ever less probative and more potentially prejudicial evidence entrusted into the jury's care (albeit under evidentiary instruction), the more an adversarial deficit is likely to emerge in terms of the parties' ability to challenge how exactly such evidence was handled in the closed confines of the deliberation room. Add to this the increasing ease with which jurors are able to obtain access to extraneous information (albeit in the teeth of stern judicial warnings against undertaking such inquiries) and the argument for greater scrutiny of their decision-making becomes all the stronger.

If it were simply the case that juries were being asked to assess information and reach decisions in a manner which corresponded with their behaviour in everyday life, they might be trusted not to deviate from 'natural' processes of decision-making. But this is very far from the case. The kind of forensic reasoning rules on which judges instruct juries do not always reflect common-sense decision-making. Admittedly, some of the more egregious examples of 'unnatural' reasoning, such as requiring juries to distinguish between evidence

complex cases: see New South Wales Law Reform Commission Report 136, Jury Directions (Sydney, New South Wales Government, 2012) [6.168].

113 MR Damaška, Evidence Law Adrift (New Haven, Yale University Press, 1997) 44.

114 Ibid 46. 
going to issues in the case and evidence going to credibility, ${ }^{115}$ are in decline. But we have seen that directions that attempt to limit the jury's reasoning to the evidence adduced in the trial grinds against a natural curiosity towards thorough investigation. The idea that juries should restrict themselves to a prescribed evidential database does not conform to the way in which decisions are made in everyday life. Although steps are being developed to equip juries with normative guidance, the more these norms depart from the natural inclinations of rational decision-makers and take on a specifically 'judicial' character designed to assure the adversarial integrity of the trial, the more, it can be argued, that juries should be required, like any other judicial body, to give some assurance that they arrived at their decision in a legally competent manner.

Of course, requiring a reasoned judgment would not guarantee that juries have in fact delivered on their oath to act only upon the evidence. What the discipline of reason-giving can do, however, is offer some means of scrutinising not only whether a verdict can be supported on the evidence but also whether the tribunal itself can justify the verdict on the basis that proper considerations were taken into account and that improper considerations were disregarded. ${ }^{116}$ It may be that the judge's summing-up once played this justificatory role. However, as juries are being required to play a more demanding 'judicial' role themselves within the closed parts of criminal proceedings, affording full integrity to this process would seem to require some explanation of how jurors applied the summing up in their deliberations and verdict.

\section{Towards More Reasoned Judgments: A Comparative Overview}

If this argument is accepted in principle, there remain, of course, considerable practical difficulties in requiring reasons from a body of 12 persons who, although required to deliberate together, can reach individual conclusions on the facts by different routes. It is sometimes said to be impossible to require jurors to give full reasons for their decisions, at least in more complex cases. ${ }^{117}$ There are certainly limits to the degree to which detailed reasons can be formulated. In order to consider how juries might be required to produce more reasoned verdicts, it is useful to advert to the practice in European countries which have retained—or in some cases resurrected—-the 'traditional' jury within their criminal justice system but have been inclined to scrutinise jury verdicts more searchingly than common law countries generally do. ${ }^{118}$

115 See eg S Lloyd-Bostock, 'The Effect on Juries of Hearing about the Defendant's Previous Criminal Record: A Simulation Study' [2000] Criminal Law Review 734.

116 See Flannery v Halifax Estate Agencies Ltd (2000) 1 WLR 377, 383 (Henry LJ).

117 See eg Blom-Cooper, above n 12, 14. But cf Lippke, above n 104, 324-25.

118 The Grand Chamber in Taxquet v Belgium [2012] 54 EHRR 26, [43], uses the term 'traditional' to characterise the 'trial-by-jury' model, the 'defining feature of which is that professional judges are unable to take part in the jurors' deliberations'. On difficulties of nomenclature and the variety of models of lay adjudication in Europe, see JD Jackson and N Kovalev, 'Lay Adjudication and Human Rights in Europe' (2006) 13 Columbia Journal of European Law 83. A surprisingly large number of continental systems operate a 'traditional' jury system. The Grand Chamber in Taxquet counted ten Council of Europe states; Switzerland has since defected, but Georgia has joined the list: see S Thaman, 'Should Criminal Juries Give Reasons for their Verdicts?' (2011) 86 Chicago-Kent Law Review 613, 619. 
During the course of the nineteenth century most European countries followed the approach taken in France and introduced a system of trial by jury in criminal cases that allowed jurors to base their decisions on their intime conviction. ${ }^{119}$ Unlike the unvarnished general verdict of 'guilty' or 'not guilty', however, continental juries were required to return an itemised special verdict or 'question list' which asked jurors to address the basic elements of the charged crimes and any possible excuses or justifications. In many jurisdictions the French characterisation of a judicial decision as an intime conviction has gradually been developed to require a more overtly reasoned verdict. ${ }^{120}$ Thus, for example, Article 120(3) of the Spanish Constitution specifically requires that 'reasons shall always be given for judgments'. When Spain re-introduced jury trial after the Franco era, the Spanish Supreme Court had to interpret how this requirement was to be applied to jury decisions. Thaman describes how the Court has vacillated between a 'flexible' approach, requiring little more than the jury restating the evidence presented at trial, and a more 'demanding' approach, requiring the jury to articulate why and how it arrived at its determination of the facts, very much resembling the explanation demanded of professional judges in 'motivating' a judgment. ${ }^{121}$

In the light of the first Taxquet decision, which put so much emphasis on the need for reasons in criminal cases as a safeguard against arbitrariness, it appeared for a while that there were only two choices facing countries with the traditional jury system: either move to require juries to give reasons or abolish trial by jury altogether. Belgium followed Spain in requiring reasons whilst the traditional juries in Switzerland and Denmark have been phased out altogether. Various approaches have been adopted to assist the jury in giving reasoned decisions. One is to invite the judge into the deliberation room after the jury has reached its verdict to help it to draft reasons. The risk here, however, is that the reasons end up being those of the professional judge and not those of the jury. Alternatively, the jury might be permitted to summon the clerk of the court or some suitably qualified lawyer to draft the reasons. ${ }^{122}$ Again, however, the danger of domination by the professional lawyer is one that might be too much to tolerate for a common law culture dedicated to the preservation of lay decision-making. Another approach is to ensure proper input by the professional judge before the jury deliberates, requiring the judge, in consultation with counsel, to put suitably detailed questions to the jury. When the questions are in 'closed' format (inviting yes/no answers) the jury's determination resembles a special verdict, but such verdicts are not fully reasoned. ${ }^{123}$ Where the questions are of a more 'open' nature, however, the jury is able to construct a fuller, more nuanced narrative. A third approach is to give the jury free rein to explain its verdict within the parameters of the judge's directions but to enable the judge to refuse to accept the reasons if they are not adequately articulated. This exercise of judicial control is analogous to common law judges' power to direct an acquittal

\footnotetext{
119 All European countries introduced jury trials in the 19th century with the exception of the Netherlands and Luxembourg: N Vidmar, 'The Jury Elsewhere in the World' in Vidmar (ed), above n 31, 429-32.

${ }^{120}$ Damaška, above n 113, 21.

121 Thaman, above n 118, 634. See also S Thaman, 'Spain Returns to Trial by Jury' (1998) 21 Hastings International \& Comparative Law Review 241; M Jimeno-Bulnes, 'A Different Story Line for Twelve Angry Men: Verdicts Reached by Majority Rule-The Spanish Perspective' (2011) 82 Chicago-Kent Law Review 759, 766.

122 This was the procedure adopted in the Canton of Geneva and is the procedure used in Spain: Thaman,

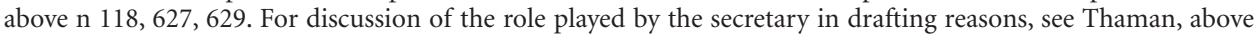
n 121, 374-76.

${ }^{123}$ This was the pre-Taxquet Belgian model: see P Traest, 'The Jury in Belgium, Lay Participation in the Criminal Trial in the XX1st Century' (2001) 72 Revue Internationale de Droit Pénal 27.
} 
(for example, for insufficiency of evidence) at any time before the jury retires, except that it would be exercised after the jury has returned its reasoned verdict. The precise parameters of this judicial jurisdiction have been disputed in Spain. Judges assuredly have the power to refuse to accept reasons that are clearly contradictory on their face. In these circumstances, the jury will be instructed to 'repair' its material omissions. More controversy surrounds the question whether a judge can refuse to accept reasons considered to be insufficient or inadequate. ${ }^{124}$

These different approaches are not mutually exclusive and others could no doubt be devised. The continental experience with reasoned verdicts has attracted mixed reviews over time. Esmein judged the system a 'fertile' one. ${ }^{125}$ For Mannheim, however, it rested on 'the fundamental mistake' of believing that the more numerous and detailed the questions were, the more jurors could be limited to the pure facts of the case. ${ }^{126}$ This arrangement proved so confusing and impracticable in Germany that, according to another commentator, it was one of the reasons why the jury system was abolished in favour of the mixed court system in $1924 .^{127}$

Two general lessons might be drawn from the continental experience. First, where enough judicial guidance is given in advance of the jury retiring and where, in particular, written instructions are provided, it is not impossible to require juries to give reasoned verdicts. One does not have to look to continental jurisdictions to vindicate this claim. Despite the demise of the civil jury, several common law countries have retained an inquest system where juries sit to deliver verdicts in certain cases. These are often special verdicts answering closed questions. However, a more narrative style has become increasingly common where inquests are the instrument by which the UK meets its procedural obligation under Article 2 of the ECHR (right to life) to investigate any death implicating agents of the state. ${ }^{128}$ In such cases, coroners are required to elicit a jury's conclusion on the central issues-by what means and in what circumstances did the deceased meet his death?extending beyond proximate causation. Although short verdicts in the traditional form will sometimes enable the jury to express its conclusion on these issues, the UK Supreme Court has said that a change of approach incorporating narrative elements may be required in certain circumstances. ${ }^{129}$ Examples of such verdicts can be found in recent high-profile cases where juries were asked to draw detailed conclusions in relation to fatal shootings by security forces in Northern Ireland. ${ }^{130}$ Findings in such cases are inevitably controversial,

124 Thaman, above n 118, 649-50.

125 A Esmein, A History of Continental Criminal Procedure with Special Reference to France (Boston, Little, Brown \& Co, 1882; trans J Simpson 1913) 416.

126 H Mannheim, 'Trial by Jury in Modern Continental Law' (1937) 53 Law Quarterly Review 99, 107. For some of the difficulties with the Spanish system, see Thaman, above n 118, 670-72.

127 F Gorphe, 'Reforms of the Jury-System in Europe: France and Other Continental Countries' (1937) 27 American Institute of Criminal Law \& Criminology 155, 158.

128 See eg Taylor v UK (1994) 79 DR 124, 137; McCann v UK (1995) 21 EHRR 97, [161]; Powell v UK Application No 45305/99, 4 May 2000; Salman v Turkey (2002) 34 EHRR 425, [104]; Jordan v UK (2001) 37 EHRR 52, [105]. Such an obligation was recognised in respect of state killings preceding the entry into force of the Human Rights Act 1998: Re McCaughey [2011] UKSC 20, [2012] 1 AC 725. Cf Re McKerr [2004] UKHL 12, [2004] 1 WLR 807.

$129 R$ (Middleton) $v$ HM Coroner for the Western District of Somerset [2004] UKHL 10, [2004] 2 AC 182.

130 See eg the narrative verdict returned by an inquest jury in the case concerning the shooting of two IRA men, McCaughey and Grew, by SAS soldiers: B McCaffrey, 'Jury Says SAS Justified in Shooting IRA Man on Ground', The Detail, 31 March 2012; www.thedetail.tv/issues/87/shoot-to-kill/jury--says-sas-justifed-in-shooting-ira-manon-ground (accessed 26 January 2016). 
prompting the question whether coroners' inquests are an appropriate forum for meeting Article 2 obligations. But narrative verdicts do at least expose the jury's reasoning in a manner that would otherwise be far more opaque if a peremptory verdict were recorded instead. ${ }^{131}$ It has since been confirmed that such verdicts may be returned in non-Article 2 inquests as well. ${ }^{132}$

Whether it is desirable to require juries to provide detailed narratives in criminal cases is another question. Here, juries are required to consider whether a number of elements in a criminal offence charged have been proved rather than more simply what led to a particular death. Although the jury must reach a conclusion that each element of the offence has been proved beyond reasonable doubt, ${ }^{133}$ it does not have to agree collectively on the weight to be given to all the items of proof that make up the evidence for each element. ${ }^{134}$ To insist that 12 jurors, or even a weighted majority of jurors, should agree on the weight to be attached to each item of proof might lead to an increase in hung juries in circumstances where juries in fact agree on the guilt of a defendant, albeit for different reasons. Even on the Continent where there has never been such a demand for unanimous or weighted majority verdicts, ${ }^{135}$ we have seen that there has been controversy over how fully reasoned a jury verdict should be. We concluded in the previous section that, while reasoned decisions may not necessarily enhance the epistemic integrity of rational decision-making, they can enhance the adversarial integrity of the trial process by opening up a closed decision-making process to more effective scrutiny. The question then arises whether greater adversarial scrutiny of this process might still be achieved without incurring the practical difficulties of requiring a fully reasoned decision from the jury.

Which brings us to a second general lesson arising from continental experience, concerning judicial activism in helping juries to justify their verdicts. Although these various intrusions into the jury's decision-making process would be more controversial if transposed to a common law environment, many common law jurisdictions have permitted judges to influence and sometimes even dictate the ultimate verdict. Under what is sometimes called the 'thirteenth juror' rule, defendants in the US may file a motion of acquittal on the ground that the evidence presented was legally insufficient for a conviction. ${ }^{136}$ Other jurisdictions permit trial judges to exercise considerable influence over the jury's reasoning in the course of their summings-up. We have seen that common law jurisdictions, including England and Wales, are intensifying this influence by encouraging judges to provide written step-bystep directions to juries that take the form of questions to be answered. In his Review of the Criminal Courts of England and Wales Auld LJ went a step further by recommending that juries be required to answer these questions publicly on the basis of the evidence presented

${ }^{131}$ For example, the narrative verdict returned by the jury in respect of the killing of Mark Duggan which led to the London riots in August 2011: V Dodd, 'Mark Duggan family reacts with fury to inquest verdict of lawful killing', The Guardian, 8 January 2014.

${ }^{132} R$ (Longfield Care Homes Ltd) v HM Coroner for Blackburn [2004] EWHC 2467 (Admin). See C Dorries, Coroners' Courts: A Guide to Law \& Practice (Oxford, Oxford University Press, 2014) [9.116]-[9.123].

133 R v Brown (Kevin) (1984) 79 Cr App R 115.

134 See JC Smith, 'Satisfying the Jury' [1988] Criminal Law Review 335; Roberts, above n 93.

135 See Jackson and Kovalev, above n 118, 113-14; EJ Leib, 'A Comparison of Criminal Jury Decision Rules in Democratic Countries' (2008) 5 Ohio State Journal of Criminal Law 629.

136 See R Allen, W Stuntz, JL Hoffmann and D Livingston, Comprehensive Criminal Procedure (New York, Aspen, 2001) 1283. For commentary see S Doran, 'The Necessarily Expanding Role of the Criminal Trial Judge' in S Doran and J Jackson (eds), The Judicial Role in Criminal Proceedings (Oxford, Hart Publishing, 2000). 
in court. ${ }^{137}$ Auld LJ rightly predicted that his proposals for a public particularisation of a jury's verdict would meet with great opposition. Special verdicts have fallen into disuse in criminal cases. ${ }^{138}$ But they are not foreign to Anglo-American jury tradition and continued in use in England and Wales until the end of the eighteenth century. ${ }^{139}$ Judges sometimes today require explanations for voluntary manslaughter verdicts when the factual basis of the conviction is unclear on its face. ${ }^{140}$

Special verdicts deal with the practical objection that jurors are not trained judges skilled in written self-justification. Of course, there is no guarantee that in answering judicially prescribed questions juries will always confine themselves to the relevant evidence and applicable law. But special verdicts do ameliorate the adversarial deficit that has been exposed when juries retire to the deliberation room and return simply to proclaim a general verdict. In discussing the manner in which states should comply with their Article 2 procedural obligation to investigate suspicious deaths, the UK Supreme Court stressed the legitimate interest that the deceased's family or next of kin be afforded an appropriate level of participation in the conduct of the investigation and that an uninformative jury verdict will be unlikely to meet that expectation. ${ }^{141}$ The Court went on to stress the importance of involving parties in making submissions on the means of eliciting the jury's factual questions and on any questions to be put, although the coroner would naturally have the final say. Adversarial process is at least as important in a criminal trial; yet although parties may have some input into judicial directions on the law, the failure to require juries to answer specific questions means the parties have less influence over how juries should go about reaching their verdict during their closed deliberation. Once the jury retires, the parties' role comes to an end except when the jury notifies the judge of any matters on which they require further assistance. It has been argued that framing directions to juries in the form of specific questions, after input from both the prosecution and defence, would enable the jury to identify more clearly the issues they have to decide and enter into an exchange in open court on the questions they were having difficulty resolving. ${ }^{142}$ The greater interaction between jury and judge that this innovation would facilitate would not only benefit juries. It would also provide a mechanism for the parties to gain an insight into what the jury is thinking, thereby promoting the integrity of adversarial proceedings throughout the deliberation stage.

There remains the objection that requiring juries to answer questions would unduly inhibit juries exercising their constitutional role of bringing in a verdict on the merits, against the law and the evidence, sometimes referred to as a perverse verdict. Juries could still be empowered to issue a general verdict after answering each question put and have the final say on whether to convict or acquit the accused, although questions would then

137 Auld Report, above n 12, ch 5, [52]-[55].

138 See $R v$ Hendrick (1921) 15 Cr App R 149, Rv Bourne (1952) 36 Cr App R 125.

139 See JH Baker, 'Criminal Courts and Procedure 1550-1800' in Baker, The Legal Profession and the Common Law (London, Hambledon Press, 1986), Thaman, above n 118, 661. For contemporary US practice, see K Nepveu, 'Beyond "Guilty" or "Not Guilty": Giving Special Verdicts in Criminal Jury Trials' (2003) 21 Yale Law \& Policy Review 263.

140 See eg $R v$ Cawthorne [1996] 2 Cr App R (S) 445.

${ }_{141} R$ (Middleton) $v$ HM Coroner for the Western District of Somerset [2004] UKHL 10, [2004] 2 AC 182, [18]. See also $R$ (Amin) $v$ Secretary of State for the Home Department [2003] 4 All ER 1264, [31].

142 Moses LJ, 'Summing Down the Summing Up', Annual Law Reform Lecture 2010, www.barcouncil.org.uk/ media/100359/li_moses_summing_down_the_summing-up.pdf (accessed 26 January 2016). 
remain about the scope of any appellate review. Ultimately, the scope to be given to the jury's constitutional or governance role has to be balanced against the need to recognise, as we have argued, that modern juries are now effectively assigned an important quasi-judicial responsibility in exercising their fact finding role. This responsibility is best regulated by injecting greater openness into the relationship between the judge, the parties and the jury.

\section{Conclusion}

It is an open question how long the 'traditional' jury will be able to hold out against ever more pressing arguments that juries should provide greater justification for their verdicts. In its Grand Chamber judgment in Taxquet the ECtHR exempted the jury from this requirement, on the ground that other procedural safeguards enable defendants to understand the reasons for their conviction. However, this rationale addresses only one dimension of a more complex issue. The important 'judicial' responsibilities which, it has been argued, are bestowed on contemporary jurors have constituted them into a body of more than merely private citizens when they take the oath to try the case and give a verdict in accordance with the evidence. When jurors were less sophisticated and had little access to the outside world once they had retired to deliberate, they could concentrate upon judging their fellow peers as citizens in the manner in which they were directed by the judge. Nowadays, however, jurors are more active in their analysis of evidence, reflecting the learning needs of a modern age. Their obligations and responsibilities in the administration of criminal justice must be rethought accordingly. Just as courtroom procedure must conform with modern fair trial standards, jurors' obligation to be fair to the parties extends, I have argued, to the closed proceedings in the jury room as well. It follows that procedural mechanisms must be crafted to enable juries to discharge this judicial role in a more fully integrative manner, by indicating the basis for their decisions, just as professional judges and tribunals must do.

Reflecting on the importance of procedural reform 30 years ago, Lord Hailsham speculated that the time had come to experiment with the idea of judges sitting with juries in a mixed court. After all, tribunal hearings already operated in this fashion and it is what many jury systems transmogrified into in continental Europe. Reform in this direction is not inevitable. There is still strong support in the UK for retaining the traditional jury. Appellate courts are, however, increasingly requiring that jurors be made aware of their 'judicial' responsibilities in the deliberation room and exhorting them to act more like lay judges than purely private citizens. Unless we give further thought to what these 'judicial' responsibilities entail for the integrity of the trial process, we risk undermining confidence in an institution that, for many centuries past, has done much to instil integrity into the administration of criminal justice. 
